\title{
PENGARUH PEMBERIAN PISANG KEPOK (Musa paradisiaca forma typical) TERHADAP KADAR GLUKOSA DARAH PUASA PADA TIKUS SPRAGUE DAWLEY PRA SINDROM METABOLIK.
}

\author{
Paramitasari Tri Wahyuni, Ahmad Syauqy ${ }^{*}$ \\ Program Studi Ilmu Gizi Fakultas Kedokteran Universitas Diponegoro \\ J1.Dr.Sutomo No.18, Semarang, Telp (024) 8453708, Email : gizifk@ undip.ac.id
}

\begin{abstract}
ABSTRAK
Background: The prevalence of metabolic syndrome (MetS) rises with increasing age. Mets primarily cause by insulin resistance. Insulin resistance result in hyperglicemia (blood glucose level higher than normal range). "Kepok" banana (Musa paradisiaca forma typical) contained dietary fiber, antioxidant, and magnesium that have potential lower blood glucose.

Objective: Investigate the effect of "kepok" banana (Musa paradisiaca forma typical) on fasting blood glucose in pra sindrome metabolic sprague dawley rats.

Method: This study was true experimental with pre-post test randomized control group design. The subject of this study were 28 male sprague dawley rats and 8-12 weeks old. The were divided into 4 groups: $K(-)$ group received standart diet, $K(+)$ group received standart diet and induced by $S T Z$ (Streptozotocin), P1 group received standart diet, induced by STZ, and "kepok" banana (Musa paradisiaca forma typical) with dose 4,5 g/200 g weight, P2 group received standart diet, induced by STZ, and "kepok" banana (Musa paradisiaca forma typical) with dose $9 \mathrm{~g} / 200 \mathrm{~g}$ weight. Blood glucose level analyzed by GOD-PAP method. The data were analized by Paired t-test and Anova..

Result: There weren't significant difference between fasting blood glucose level before and after treatment in K(-) and $(K+)$ group. However, there were significant difference between fasting blood glucose level before and after treatment with "kepok" banana (Musa paradisiaca forma typical). The mean value of fasting blood glucose level

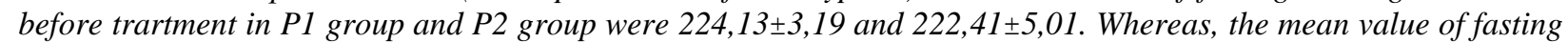

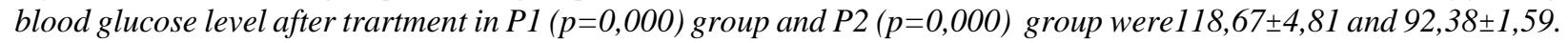
Conclusion: 21 days treatment of "kepok" banana (Musa paradisiaca forma typical) with dose 4,5 g/200 $\mathrm{g}$ weight and $9 \mathrm{~g} / 200 \mathrm{~g}$ weight can lower fasting blood glucose levels 47,5\% and 58,46\% in male pra metabolic syndrome sprague dawley rats.
\end{abstract}

Keyword: “kepok” banana (Musa paradisiaca forma typical), fasting blood glucose level, pra metabolic syndrome.

\begin{abstract}
ABSTRAK
Latar Belakang: Seiring dengan bertambahnya usia maka prevalensi sindrom metabolik juga akan meningkat. Sindrom metabolik utamanya diakibatkan karena resistensi insulin. Resistan insulin mengakibatkan hiperglikemia (kadar glukosa darah diatas normal). Pisang kepok kuning (Musa paradisiaca forma typical) merupakan buah yang mengandung serat, antioksidan, dan magnesium yang berpotensi menurunkan kadar glukosa darah.

Tujuan: mengetahui pengaruh pemberian pisang kepok (Musa paradisiaca forma typical) terhadap kadar glukosa darah puasa pada tikus Sprague Dawley pra sindrom metabolik

Metode: Penelitian true experimental dengan pre-post test randomized control group design. Subjek penelitian 28 ekor tikus Sprague Dawley jantan usia 8-12 minggu, dibagi secara acak dalam 4 kelompok kontrol negatif yang hanya diberikan pakan standar, kontrol positif yang diberikan pakan standard dan induksi STZ(Streptozotocin). Dua kelompok perlakuan diberikan pakan standar, induksi STZ dan buah pisang kepok kuning (Musa paradisiaca forma typical) dengan dosis 4,5g/200gBB dan 9g/200gBB selama 21 hari. Kadar glukosa darah diperiksa dengan metode GOD-PAP. Data dianalisis dengan uji Paired t-test dan Anova

Hasil: Tidak terdapat perbedaan yang bermakna sebelum dan setelah intervensi pada kelompok $K(-)$ dan $K(+)$. Namun terdapat perbedaan yang bermakna sebelum dan setelah intervensi pada kelompok P1 dan P2. Rerata kadar

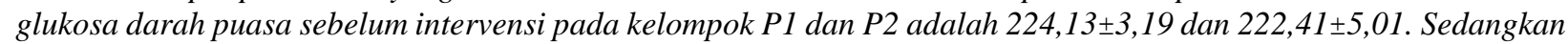
rerata glukosa darah puasa setelah intervensi pada kelompok $P 1(p=0,000)$ dan P2 $(p=0,000)$ adalah 118,67 $\pm 4,81$

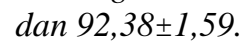

Kesimpulan: Pemberian pisang kepok kuning (Musa paradisiaca forma typical) selama 21 hari pada dosis 4,5 g/200 g BB/hari dan $9 \mathrm{~g} / 200 \mathrm{~g}$ BB/hari dapat menurunkan kadar glukosa darah puasa masing-masing sebesar 47,05\% dan $58,46 \%$ pada tikus sprague dawley pra sindrom metabolik.
\end{abstract}

Kata Kunci: pisang kepok kuning (Musa paradisiaca forma typical), kadar glukosa darah puasa, pra sindrom metabolik

${ }^{*}$ Penulis Penanggungjawab 


\section{PENDAHULUAN}

Prevalensi sindrom metabolik mengalami peningkatan di semua negara di dunia. Menurut National Health and Nutrition Examination Survey (NHANES) tahun 1988 hingga tahun 2000 prevalensi sindrom metabolik meningkat. ${ }^{1}$ Seiring dengan bertambahnya usia maka prevalensi sindrom metabolik juga akan meningkat. ${ }^{1}$ Berdasarkan penelitian Beltrán-Sánchez et al prevalensi sindrom metabolik di Amerika Serikat dari tahun 1999 hingga 2010 menurun. Meskipun dikatakan menurun, prevalensi sindrom metabolik di Amerika Serikat masih sekitar 22\% untuk kategori dewasa atau tiga dari lima orang dewasa di Amerika Serikat menderita sindrom metabolik. ${ }^{2}$ Di Indonesia dilakukan penelitian oleh Suastika dkk, yang mengambil subjek di masyarakat pedesaan Bali sebanyak 501 subjek dan didapatkan prevalensi sindrom metabolik sebesar $18,2 \%{ }^{3}$

Sindrom metabolik adalah kumpulan dari kelainan metabolik baik lipid maupun non-lipid dengan tanda dan gejala seperti peningkatan ukuran lingkar pinggang, peningkatan kadar trigliserida darah, kadar HDL kolesterol yang rendah, tekanan darah tinggi, dan kadar gula darah puasa. ${ }^{4}$ Berdasarkan National Cholesterol Education Program yang dimodifikasi untuk kawasan Asia, dinyatakan seseorang menderita sindrom metabolik bila mempunyai $\geq 3$ dari 5 tanda dan gejala tersebut. Pra sindrom metabolik merupakan kumpulan dari 1 atau 2 faktor resiko sindrom metabolik. ${ }^{5}$

Sindrom metabolik utamanya diakibatkan karena resistensi insulin. ${ }^{6,7}$ Resistensi insulin adalah berkurangnya sensitivitas insulin di dalam otot, jaringan adiposa, dan sel hati. Akibatnya sel $\beta$ pankreas melepaskan lebih banyak insulin untuk menjaga glukosa darah tetap normal sehingga insulin dalam darah meningkat ke level abnormal (hiperinsulinemia). ${ }^{8}$ Seiring waktu, pankreas menjadi tidak mampu mengimbangi penurunan sensitivitas sel pada insulin dan terjadi hiperglikemia (kadar glukosa darah diatas normal). ${ }^{9}$ Insulin merupakan hormon yang mengontrol kadar glukosa darah di dalam tubuh. Resistensi insulin mengakibatkan kadar glukosa darah tidak terkontrol. ${ }^{8,10}$

Pisang merupakan salah satu jenis buah yang mengandung antioksidan, vitamin dan mineral yang penting untuk tubuh, serta serat harian yang dibutuhkan tubuh. Pisang merupakan karbohidrat kompleks dan simpleks sehingga pisang dapat digunakan sebagai sumber energi untuk meningkatkan daya tahan tubuh. ${ }^{11,12}$ Pisang juga berperan dalam menurunkan kadar glukosa darah dan kadar kolesterol. Efek hipoglikemik atau penurunan kadar glukosa darah dapat terlihat setelah mengkonsumsi satu hingga dua buah ( $250 \mathrm{~g}$ ) pisang dalam sehari. Efek hipoglikemik dapat terjadi karena pisang mengandung beberapa senyawa aktif seperti serat, flavonoid, dan magnesium. ${ }^{13}$

Serat memiliki efek positif terhadap kadar glukosa darah. Pisang kepok mengandung serat seperti pati resisten dan inulin yang berpengaruh positif terhadap kadar glukosa darah. Inulin dapat meningkatkan produksi SCFA (Short Chain Fatty Acid) di dalam usus. ${ }^{14}$ SCFA berpengaruh pada metabolisme insulin di dalam tubuh sehingga efek hipoglikemik dapat terjadi. ${ }^{14}$ Flavonoid pada pisang dapat meningkatkan sensitifitas insulin dengan membersihkan jalur sinyal insulin. Flavonoid pada pisang juga dapat menurunkan konsentrasi kolesterol dalam darah. ${ }^{13}$

Pisang yang digunakan dalam penelitian ini adalah pisang kepok kuning (Musa paradisiaca forma typical). Pisang kepok termasuk dalam pisang plantain atau pisang olahan. ${ }^{15}$ Meskipun pisang kepok merupakan jenis pisang olahan, pisang kepok juga dapat dikonsumsi secara langsung ketika pisang sudah matang. Pati resisten pisang kepok merupakan yang paling tinggi dibandingkan pati resisten pisang lain. ${ }^{16}$ Pati resisten juga dapat menurunkan kadar glukosa darah. ${ }^{17}$ Pisang merupakan buah dengan kandungan inulin yang paling tinggi yaitu sekitar $1 \mathrm{~g} / 100 \mathrm{~g} .{ }^{18}$ Pisang kepok kuning memiliki rasa yang lebih manis dibandingkan dengan pisang kepok putih. Pisang kepok kuning memiliki kandungan karotenoid, khususnya $\beta$ karoten. Kandungan $\beta$ karoten pada pisang kepok sekitar 2,4 mg/100g pisang kepok. ${ }^{19} \beta$ karoten merupakan antioksidan yang mempunyai peran sebagai hipoglikemik dan dapat menekan lipid peroksida di dalam jaringan sehingga dapat mengurangi komplikasi diabetes melitus. ${ }^{20}$

Penelitian sebelumnya meneliti pengaruh pisang terhadap kadar glukosa darah pada subjek manusia diabetes tipe 2 dan hiperkolesterolemia dengan dosis $250 \mathrm{~g} /$ hari dan $500 \mathrm{~g} /$ hari. Pisang dengan dosis $250 \mathrm{~g} /$ hari secara signifikan dapat menurunkan kadar glukosa darah subjek sedangkan kadar kolesterol menurun namun tidak signifikan. Pisang dengan dosis $500 \mathrm{~g} /$ hari secara signifikan dapat menurunkan kadar glukosa darah dan kadar kolesterol total subjek. Hal inilah yang mendorong peneliti untuk melakukan penelitian dengan jenis pisang yang berbeda, dan kondisi subjek yang berbeda dengan tujuan mengetahui pengaruh pemberian pisang kepok (Musa paradisiaca forma typical) terhadap kadar glukosa darah pada tikus 
Sprague Dawley pra sindrom metabolik. Jenis tikus Sprague Dawley dipilih karena lebih sensitif terhadap diet tinggi lemak dan metabolismenya lebih mirip dengan manusia.

\section{METODE PENELITIAN}

Jenis penelitian ini adalah eksperimental murni laboratorium dengan rancangan penelitian true experimental dengan pre-post test randomized control group design. Variabel bebas (independent variable) adalah pemberian buah pisang kepok kuning. Variabel terikat (dependent variable) adalah kadar glukosa darah. Kriteria inklusi adalah tikus jantan galur sprague Dawley dan usia tikus 812 minggu. Sedangkan kriteria ekslusinya tikus mengalami perubahan perilaku (penurunan nafsu makan dan lemas), tikus sakit, dan tikus mati saat penelitian. Penelitian ini dilaksanakan selama 28 hari di Laboratorium Pusat Pangan dan Gizi Universitas Gajah Mada Yogjakarta.

Uji Kandungan juga dilakukan untuk mengetahui jumlah dari kandungan zat gizi yang ada di dalam buah pisang kepok kuning. Uji proksimat (kadar abu total, kadar air total, kadar lemak total, kadar protein total, dan kadar karbohidrat total) dilakukan dengan metode yang berbeda. Uji kadar abu total menggunakan metode Drying Ash, uji kadar air total menggunakan metode Termogravimetri, uji kadar lemak total menggunakan metode Soxhletasi, uji kadar protein total menggunakan metode Kjeldahl, dan uji karbohidrat total dalam sampel dihitung berdasarkan perhitungan (dalam $\%)^{21}$ :

$\%$ karbohidrat $=100 \%-\%($ protein + lemak + abu + air)

Uji kandungan aktifitas antioksidan menggunakan 1,1-diphenyl-2-picrylhydrazyl $(\mathrm{DPPH})^{22}$ serta uji kandungan inulin dilakukan dengan metode HPLC (High Performance Liquid Chromatography) atau Kromatografi Cair Kinerja Tinggi (KCKT). ${ }^{23}$

Subjek yang digunakan adalah tikus Sprague Dawley jantan berusia 8-12 minggu. Tikus diperoleh dari peternak Java petshop Yogjakarta. Besar sampel penelitian ditentukan dengan rumus Federer sehingga diperoleh sampel 6 ekor per kelompok perlakuan. Namun, untuk menghindari adanya tikus yang mati saat adaptasi dan perlakuan maka digunakan 7 ekor tikus setiap kelompok. Selama penelitian tidak terdapat tikus yang mati ataupun masuk dalam kriteria ekslusi.

Tikus Sprague Dawley berumur 8-12 minggu sebanyak 28 ekor diaklimatisasi di Laboratorium Pusat Pangan dan Gizi UGM selama 3 hari menggunakan kandang individu dan mendapat pakan standar jenis AD II dan minum $a d$ libitum. Selanjutnya dengan simple random sampling, subjek dibagi menjadi 4 kemompok perlakuan yaitu kelompok kontrol positif, kelompok kontrol negatif, kelompok perlakuan 1, dan kelompok perlakuan 2. Selanjutnya pada kelompok kontrol negatif, kelompok perlakuan 1, dan kelompok perlakuan 2 dengan pemberian induksi Strepzotocin (STZ) $65 \mathrm{mg} / \mathrm{kg}$ BB dan Nicotinamide (NAD) $230 \mathrm{mg} / \mathrm{kg}$ BB tikus. $^{24}$ Induksi STZ dilakukan sebanyak satu kali dan dibutuhkan waktu 5 hari untuk meningkatkan kadar glukosa darah. Setelah 5 hari tikus dipuasakan selama 12 jam dan selanjutnya dilakukan pengambilan darah tikus di bagian mata (pleksus retroorbitalis) untuk menganalisis glukosa darah sebelum perlakuan ( $p r e$ test).

Setelah dilakukan pre test, selanjutnya tikus di intervensi. Intervensi yang diberikan yaitu pemberian lumatan pisang kepok kuning matang (pisang kepok kuning matang yang telah di kupas dan diambil daging buahnya kemudian diblender untuk mendapatkan tekstur pisang lumat). Pada saat intervensi kelompok kontrol mendapat pakan standar dan air ad libitum. Kelompok perlakuan 1 mendapat pakan standar, air ad libitum dan pisang kepok kuning sebanyak 4,5 g/200 gram BB tikus. Kelompok perlakuan 2 mendapat pakan standar, air ad libitum dan pisang kepok kuning sebanyak 9 $\mathrm{g} / 200$ gram BB tikus. Intervensi dilakukan selama 21 hari. Pemberian lumatan buah pisang kepok kuning dilakukan dengan cara sonde. Komposisi pakan standart AD II adalah air 12\%, protein kasar $15 \%$, lemak kasar $7 \%$, serat kasar $6 \%$, abu $7 \%$, kalsium $1,1 \%$, phosphor $0,9 \%$, antibiotik dan coccidiostat.

Pengambilan darah yang kedua dilakukan pada hari ke 29 yang sebelumnya tikus dipuasakan selama 12 jam. Sampel darah diambil melalui pleksus retroorbitalis untuk pemeriksaan kadar glukosa darah tikus setelah perlakuan/intervensi. Kadar glukosa darah diukur dengan metode glukosa oksidase $(G O D \quad P A P)$ menggunakan spektrofotometer. ${ }^{10}$

Data yang diperoleh dianalisis menggunakan komputer. Data tersebut diuji kenormalitasnya menggunakan uji Shapiro-wilk karena jumlah sampel $\leq 50$. Perbedaan kadar glukosa darah sebelum dan setelah perlakuan dapat diketahui dengan melakukan uji Paired t-test (uji $\mathrm{t}$ berpasangan). Perbedaan pengaruh dosis dari keempat kelompok perlakuan dianalisis menggunakan uji statistik Anova dan selajutnya di uji lanjut dengan Uji Post Hoc LSD. Perbedaan berat badan sebelum induksi STZ (awal penelitian), 
setelah induksi STZ dan setelah intervensi (setelah perlakuan) dapat diketahui dengan melakukan uji Paired $t$ test (uji $\mathrm{t}$ berpasangan) untuk data berdistribusi normal dan uji wilcoxon untuk data berdistribusi tidak normal. Perbedaan perubahan berat badan setiap kelompok dianalisis menggunakan uji statistik Kruskal Wallis karena data berdistribusi tidak normal. ${ }^{25}$

\section{HASIL PENELITIAN}

Penelitian ini dilakukan untuk melihat pengaruh pemberian pisang kepok kuning terhadap kadar glukosa darah tikus Sprague Dawley pra sindrom metabolik. Menurut penelitian sebelumnya pisang telah terbukti dapat menurunkan kadar glukosa darah karena mengandung zat fitokimia berupa antioksidan, serat, dan inulin.

\section{Kandungan Zat Gizi Pisang Kepok Kuning}

Kandungan zat gizi 100 gram buah pisang kepok kuning di tampilkan dalam tabel 1 berikut:

Tabel 1. Kandungan zat gizi 100 gram buah pisang kepok

\begin{tabular}{ll}
\hline Zat Gizi & $\% / 100 \mathrm{~g}$ pisang kepok kuning \\
\hline Air & 65,54 \\
Abu & 0,72 \\
Lemak & 0,95 \\
Protein & 1,75 \\
Karbohidrat & 31,04 \\
\hline Jumlah & $\mathbf{1 0 0 \%}$ \\
\hline Aktifitas Antioksidan & 12,35 \\
Serat Kasar & 1,14 \\
Inulin & 0,13 \\
\hline
\end{tabular}

Analisis kandungan zat gizi dilakukan di Laboratorium Pangan dan Gizi Universitas Gadjah Mada Yogyakarta. Namun, kandungan zat gizi inulin di analisis di LPPT Universitas Gadjah Mada. Uji kandungan zat gizi dilakukan untuk mengetahui jumlah pasti zat gizi yang terkandung dalam pisang kepok yang selanjutnya zat gizi tersebut dapat mempengaruhi kadar glukosa darah.

Kondisi Setelah Induksi Streptozotocin (STZ) dan Nicotinamide (NAD)

Tabel di bawah ini merupakan hasil dari kadar glukosa darah puasa dan kadar trigliserida pada tikus setelah induksi STZ.

Tabel 2. Hasil kondisi setelah induksi STZ dan NAD

\begin{tabular}{lll}
\hline Kategori & Normal & $\begin{array}{l}\text { Hasil } \\
\text { Rerata } \pm \text { s.b }\end{array}$ \\
\hline Kadar Glukosa darah puasa & $55-135 \mathrm{mg} / \mathrm{dL}$ & $221,18 \pm 1,29$ \\
Kadar Trigliserida & $25-145 \mathrm{mg} / \mathrm{dL}$ & $81,6 \pm 6,95$ \\
Kadar Kolesterol Total & $<110 \mathrm{mg} / \mathrm{dL}$ & $179,05 \pm 6,27$ \\
\hline
\end{tabular}

Setelah di induksi dengan STZ dan NAD tikus mengalami hiperglikemia dan hiperkolesterolmia tetapi tidak mengalami hipertrigliserida. Kadar trigliserida tikus masih tergolong normal, sehingga kondisi pra sindrom metabolik tidak tercapai.

\section{Analisis Berat Badan Tikus Awal Penelitian, Setelah Induksi Streptozotocin (STZ) dan Setelah intervensi}

Tabel dibawah ini menunjukan perbedaan berat badan tikus pada sebelum induksi STZ (awal penelitian), setelah induksi STZ dan pada setelah intervensi. Penimbangan berat badan dilakukan setiap 3 hari sekali. Hasil analisis berat badan ditunjukan pada tabel berikut:

Tabel 3. Hasil Analisis Rerata Berat Badan Subjek Sebelum dan Sesudah Induksi STZ

\begin{tabular}{lllllll}
\hline $\begin{array}{l}\text { Berat } \\
\text { badan }\end{array}$ & $\mathrm{N}$ & $\begin{array}{l}\text { Sebelum } \\
\text { Rerata } \pm \text { s.b. } \\
\text { gram) }\end{array}$ & $\begin{array}{l}\text { Sesudah } \\
\text { Rerata } \pm \text { s.b. } \\
\text { (gram) }\end{array}$ & $\begin{array}{l}\Delta \\
\text { Rerata } \pm \text { s.b } \\
\text { gram) }\end{array}$ & $\% \Delta$ & $P$ \\
\hline $\mathrm{K}-$ & 7 & $108,14 \pm 16,48$ & $112,57 \pm 18,13$ & $4,42 \pm 2,22^{\mathrm{a}}$ & 4,08 & $0,002^{\mathrm{b}^{*}}$ \\
$\mathrm{~K}+$ & 7 & $144,42 \pm 28,28$ & $139,71 \pm 24,98$ & $-4,71 \pm 3,35^{\mathrm{a}}$ & $-3,26$ & $0,018^{\mathrm{c}^{*}}$ \\
$\mathrm{P} 1$ & 7 & $125,71 \pm 9,65$ & $122,00 \pm 7,72$ & $-3,71 \pm 3,03^{\mathrm{a}}$ & $-2,95$ & $0,018^{\mathrm{b}^{*}}$ \\
\hline
\end{tabular}




\begin{tabular}{lllllll}
\hline P2 & 7 & $123,28 \pm 24,75$ & $116,28 \pm 27,75$ & $-7,00 \pm 4,61^{\text {a }}$ & $-5,67$ & $0,007^{b^{*}}$ \\
\hline
\end{tabular}

${ }^{a}$ Uji Kruskal-Wallis

${ }^{b}$ Uji Paired t-test

${ }^{c}$ Uji Wilcoxon

*berbeda bermakna

Keterangan : K- : kelompok kontrol negatif

$\mathrm{K}+$ :kelompok kontrol positif

$\mathrm{P} 1$ : kelompok perlakuan pisang kepok $4,5 \mathrm{~g}$

P2 : kelompok perlakuan pisang kepok $9 \mathrm{~g}$

Tabel diatas menunjukan terdapat dan setelah perlakuan $(\mathrm{p}=0,000)$. Secara deskriptif perbedaan yang bermakna berat badan sebelum dan perubahan berat badan terendah yaitu pada setelah induksi STZ pada semua kelompok. Hasil kelompok perlakuan 1 sebesar 2,95\% dan analisis perubahan berat badan sampel yang di uji perubahan berat badan yang tertinggi yaitu pada dengan uji Kruskall wallis menunjukan bahwa kelompok perlakuan 2 sebesar 5,67\%. terdapat perbedaan perubahan berat badan sebelum

Tabel 4. Hasil Analisis Rerata Berat Badan Sampel Setelah Induksi STZ dan Setelah Intervensi

\begin{tabular}{|c|c|c|c|c|c|}
\hline \multirow{2}{*}{ Kelompok } & $\begin{array}{l}\text { Setelah induksi } \\
\text { STZ }\end{array}$ & $\begin{array}{l}\text { Setelah } \\
\text { intervensi }\end{array}$ & \multirow{2}{*}{$\begin{array}{l}\Delta \\
\text { Rerata } \pm \text { SD } \\
(\mathrm{g})\end{array}$} & \multirow[t]{2}{*}{$\% \Delta$} & \multirow{2}{*}{$\boldsymbol{P}$} \\
\hline & $\begin{array}{l}\text { Rerata } \pm \text { SD } \\
(\mathrm{g})\end{array}$ & $\begin{array}{l}\text { Rerata } \pm S D \\
(\mathrm{~g})\end{array}$ & & & \\
\hline K- & $112,57 \pm 18,13^{a}$ & $133,57 \pm 18,13^{\mathrm{a}}$ & $21 \pm 0,00^{c}$ & $18,6 \%$ & $0,008^{a *}$ \\
\hline $\mathrm{K}+$ & $139,71 \pm 24,98^{\mathrm{a}}$ & $125,85 \pm 24,81^{\mathrm{a}}$ & $-13,85 \pm 0,89^{c}$ & $-0,09 \%$ & $0,014^{\mathrm{a} *}$ \\
\hline $\mathrm{P} 1$ & $122 \pm 7,72^{\mathrm{b}}$ & $142,71 \pm 7,93^{\mathrm{b}}$ & $20,71 \pm 0,48^{\mathrm{c}}$ & $16,97 \%$ & $0,000^{\mathrm{b} *}$ \\
\hline $\mathrm{P} 2$ & $116,28 \pm 27,75^{b}$ & $137,28 \pm 28,15^{b}$ & $21 \pm 0,57^{\mathrm{c}}$ & $18,05 \%$ & $0,000^{\mathrm{b} *}$ \\
\hline
\end{tabular}

${ }^{\text {a }}$ wilcoxon

${ }^{\mathrm{b}}$ paired t test

${ }^{\mathrm{c}}$ Kruskall Wallis

*beda bermakna

Berdasarkan tabel 3 terdapat perbedaan yang bermakna berat badan setelah induksi STZ dan setelah intervensi pada semua kelompok. Hasil analisis perubahan berat badan sampel yang di uji dengan uji Kruskall wallis menunjukan bahwa terdapat perbedaan perubahan berat badan sebelum dan setelah perlakuan $(p=0,000)$. Secara deskriptif perubahan berat badan terendah yaitu pada kelompok kontrol positif sebesar 0,09\% dan perubahan berat badan yang tertinggi yaitu pada kelompok kontrol negatif sebesar 18,6\%.

\section{Analisis Kadar Glukosa Darah Sebelum dan Setelah Perlakuan}

Tabel dibawah menunjukan perbedaan kadar glukosa darah sebelum dan setelah perlakuan serta perbedaan perubahan kadar glukosa darah sebelum dan setelah perlakuan.

Tabel 5. Hasil Analisis Kadar Glukosa Darah

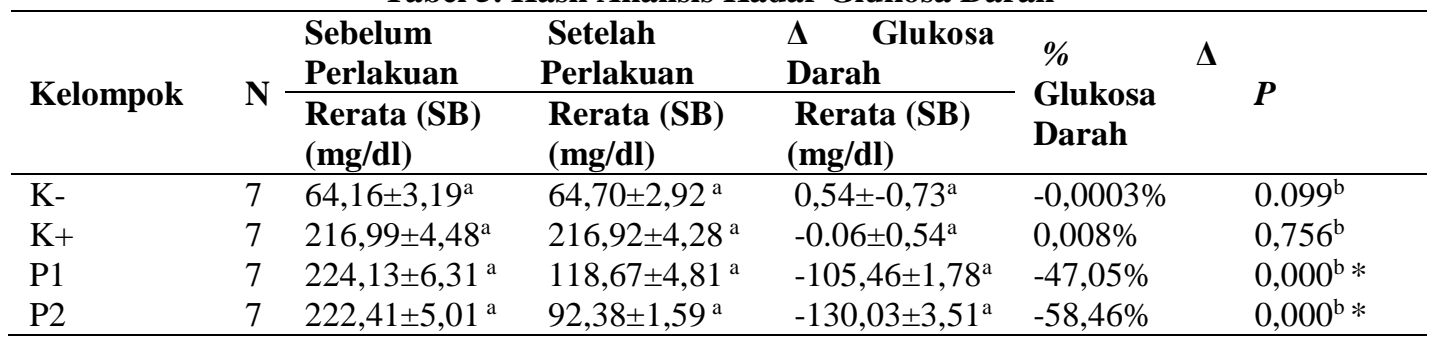

${ }^{a}$ Uji Anova

${ }^{b}$ paired t test

*beda bermakna

Uji Post Hoc LSD sebelum perlakuan: $\mathrm{K}(-)$ vs $\mathrm{K}(+) p=0,000 ; \mathrm{K}(-)$ vs $\mathrm{P} 1 p=0,000 ; \mathrm{K}(-)$ vs $\mathrm{P} 2 p=0,000 ; \mathrm{K}(+)$ vs $\mathrm{P} 1 p=$ 0,$011 ; \mathrm{K}(+)$ vs $\mathrm{P} 2 p=0,049 ; \mathrm{P} 1$ vs $\mathrm{P} 2 p=0,515$. Setelah perlakuan diperoleh semua perbedaan antar kelompok $p=0,000$.

Tabel 4 menunjukan bahwa tidak terdapat perbedaan bermakna antara kadar glukosa darah sebelum dan setelah intervensi $(p>0,05)$ pada kelompok kontrol positif dan kontrol negatif. 
Sedangkan pada kelompok perlakuan 1 dan perlakuan 2 terdapat perbedaan yang bermakna antara kadar glukosa darah sebelum dan setelah intervensi selama 21 hari $(\mathrm{p}=0,000)$. Berdasarkan Anova diatas, terdapat perbedaan yang bermakna semua kelompok sebelum dan setelah perlakuan dan terdapat perbedaan perubahan kadar glukosa darah yang bermakna antar kelompok sebelum perlakuan maupun setelah perlakuan $(\mathrm{p}=0,000)$. Hasil uji beda rerata glukosa darah antar kelompok menunjukan terdapat perbedaan perubahan kadar glukosa darah antar kelompok perlakuan $(\mathrm{p}=0,000)$, serta secara deskriptif penurunan kadar glukosa pada kelompok perlakuan 1 dan pelakuan 2. Penurunan kadar glukosa darah tertinggi terdapat pada kelompok perlakuan 2 yaitu sebesar $58,46 \%$.

Berdasarkan uji Anova diatas ,terdapat perbedaan kadar glukosa darah yang bermakna antar kelompok sebelum perlakuan maupun setelah perlakuan $(\mathrm{p}=0,000)$. Perbedaan yang bermakna antar kelompok setelah intervensi dapat diketahui dengan uji Post Hoc LSD yang menunjukan terdapat perbedaan yang bermakna antar semua kelompok $(p<0,05)$, kecuali pada kelompok perlakuan 1 dan perlakuan 2. Kelompok perlakuan 1 dan perlakuan 2 tidak memiliki perbedaan yang bermakna $(p=0,515)$. Uji Post Hoc LSD setelah perlakuan menunjukan terdapat perbedaan yang bermakna antar semua kelompok $(\mathrm{p}=0,000)$, baik kelompok perlakuan maupun kelompok kontrol.

\section{PEMBAHASAN}

\section{Kandungan zat gizi pisang kepok kuning}

Analisis kandungan zat gizi pada buah pisang sudah pernah dilakukan sebelumnya. Jenis pisang kepok kuning analisis zat gizi sudah pernah dilakukan, namun hanya dalam batas menganalisis pati resisten dan beberapa zat gizi lain seperti antioksidan, serat, inulin secara kualitatif. Hasil analisis zat gizi pada tabel 1 per $100 \mathrm{~g}$ pisang kepok kuning menunjukan kandungan air pada pisang kepok kuning mencapai 65,5\%, kandungan karbohidrat sebesar 31,89\%, kandungan antioksidan $12,3 \%$, Protein $1,75 \%$, Serat kasar $1,14 \%$, lemak $0,95 \%$, abu $0,72 \%$, dan inulin $0,1265 \%$. Kandungan serat kasar pada pisang kepok kuning dua kali lebih tinggi dibanding serat kasar yang ada di pisang segar yang hanya sekitar $0,5 \mathrm{~g} / 100 \mathrm{~g}$ pisang segar. $^{26}$ Sedangkan jika dibandingkan dengan kandungan inulin pada ekstrak buah pisang yaitu 2,1\% kandungan inulin pada buah pisang kepok kuning lebih kecil. ${ }^{27}$ Kandungan pati resisten pada buah pisang kepok kuning adalah $27,70 \% .^{16}$

\section{Kondisi Setelah Induksi Streptozotoxin dan Nicotinamide}

Rata-rata kadar glukosa darah puasa tikus setelah di induksi STZ adalah $221,18 \mathrm{mg} / \mathrm{dL}$ dalam kurun waktu 5 hari. STZ umumnya dapat meningkatkan kadar glukosa darah hingga $>300$ $\mathrm{mg} / \mathrm{dl}$ selama kurun waktu 3 hari ${ }^{28}$ dan $>250 \mathrm{mg} / \mathrm{dl}$ dalam kurun waktu 1 minggu. ${ }^{29}$ Mekanisme STZ dalam meningkatkan kadar glukosa darah adalah sebagi berikut Streptozotocin (STZ) masuk ke dalam sel $\beta$ pankreas melalui GLUT 2 menuju membran plasma. ${ }^{30}$ Proses kerusakan sel $\beta$ pankreas berawal dari penurunan ATP dengan cara menginhibisi siklus krebs dan menginduksi NO sehingga akan terbentuk ROS yang mengakbatkan kerusakan DNA. Gugus alkil yang terdapat pada STZ dapat menyebabkan terjadinya alkilasi pada DNA. ${ }^{24}$ Alkilasi tersebut akan mengaktivasi poli (ADP-ribosilasion) yang menurunkan NAD dan ATP yang akan menyebabkan nekrosis dan kerusakan pada sel $\beta$ pankreas. ${ }^{31}$

Terdapat 3 fase setelah penyuntikan STZ pada hewan coba hingga terjadinya hiperglikemi. Fase pertama berlangsung selama 2 hingga 4 jam. Fase ini dimulai dengan terjadinya peningkatan glukosa darah setelah satu jam injeksi. Penurunan konsentrasi insulin pada pembuluh darah terjadi pada fase ini. Fase kedua yaitu hipoglikemi yang terjadi 4 sampai 8 jam setelah injeksi. Pemberian konsetrat glukosa seperti Nicotinamide diperlukan untuk mencegah terjadinya kematian akibat hipoglikemi. Nicotinamide merupakan antioksidan yang memiliki efek protektif pada aktivitas sitokin dari STZ dengan cara mendekteksi radikal bebas yang dapat menyebabkan kerusakan minor pada sel $\beta$ pankreas. ${ }^{32}$ Pecahnya sel $\beta$ yang mengandung insulin mengakibatkan hipoglikemi terjadi. Insulin akan beredar ke pembuluh darah dan berikatan dengan reseptor di sel lemak dan otot, menyebabkan penurunan glukosa darah dengan cepat. Pada fase ketiga terjadi hiperglikemi yang permanen. Pemeriksaan morfologii menunjukan adanya kerusakan yang besar pada hampir seluruh sel $\beta$ dalam kurun waktu 12-24 jam setelah injeksi STZ. 24

Kondisi pra sindrom metabolik yang diharapkan pada penelitian ini adalah hiperglikemia dan hipertrigliserida. Kondisi pra sindrom metabolik didapatkan melalui induks Streptozotocin (STZ) $65 \mathrm{mg} / \mathrm{kg}$ BB dan Nicotinamide (NAD) 230 $\mathrm{mg} / \mathrm{kg} \mathrm{BB}$. Induksi STZ dan NAD hanya sekali diberikan. Pemilihan induksi ini dilakukan karena STZ memiliki efek diabetogenik yang juga diikuti terjadinya peningkatan kadar kolesterol. Kondisi pra sindrom metabolik diketahui dengan cara 
membandingkan kadar glukosa darah dan kadar trigliserida pada tikus yang mendapat injeksi STZ dan NAD dengan kelompok kontrol negatif yang mendapat pakan standar. Kadar glukosa darah dan kadar trigliserida kelompok kontrol negatif digunakan sebagai gambaran kadar glukosa dan trigliserida tikus normal.

Rerata kadar glukosa darah puasa setelah induksi STZ pada kelompok kontrol negatif adalah $64,16 \mathrm{mg} / \mathrm{dL}$. Sedangkan rerata kadar glukosa darah puasa tikus setelah di induksi STZ adalah 221,18 $\mathrm{mg} / \mathrm{dL}$. Kadar glukosa darah puasa setelah induksi STZ pada kontrol negatif dan kelompok perlakuan lebih tinggi dibandingkan dengan kelompok kontrol negatif. Tikus pada kelompok kontrol positif dan kelompok perlakuan mengalami hiperglikemia $(>135 \mathrm{mg} / \mathrm{dL}){ }^{33}$

Rerata kadar trigliserida setelah induksi STZ pada kelompok kontrol negatif adalah 37,7 $\mathrm{mg} / \mathrm{dL}$. Sedangkan rerata kadar trigliserida pada kelompok kontrol positif dan kelompok perlakuan adalah 81,6 mg/dL. Kadar trigliserida setelah induksi STZ pada kontrol negatif dan kelompok perlakuan lebih tinggi dibandingkan dengan kelompok kontrol negatif. Meskipun kadar trigliserida pada kelompok kontrol positif dan kelompok perlakuan lebih tinggi di banding kelompok positif, kadar trigliserida tidak mencapai hipertrigliserida(>145 mg/dL). Meskipun kadar trigliserida masih dalam rerata normal, terjadi peningkatan kadar kolesterol total diatas normal sehingga tikus menjadi hiperkolesterolemia. Hal ini mengakibatkan kondisi pra sindrom metabolik tidak tercapai, tapi berisiko menjadi pra sindrom metabolik.

Mekanisme STZ dalam meningkatkan kadar trigliserida diawali dengan penurunan sekresi dan penurunan sensitifitas insulin. Penurunan sekresi dan penurunan sensitifitas insulin menyebabkan terjadinya defisiensi insulin sehingga meningkatkan degradasi lemak. Akibatnya, terjadi akumulasi lemak. Akumulasi lemak akan diambil oleh hati untuk sintesis lipoprotein dan sisanya dipecah menjadi Acetyl CoA yang akan digunakan dalam siklus asam trikarboksilat. Jika akumulasi lemak besar maka jumlah lemak yang masuk dalam hati untuk sintesis lipoprotein akan bertambah, sehingga akan mengakibatkan hiperlipidemia (kadar kolesterol dan trigliserida meningkat). ${ }^{34}$ Namun, akumulasi lemak yang terbentuk dalam tubuh tikus tidak terlalu banyak sehingga tidak terjadi hiperlipidemia dan kadar trigliserida tidak melebihi batas normal.

\section{Berat Badan Sampel Sebelum, Setelah Induksi STZ dan setelah intervensi}

Berdasarkan hasil statistik terdapat perbedaan yang bermakna pada berat badan sampel sebelum, setelah induksi STZ, dan akhir perlakuan pada semua kelompok perlakuan. Hasil analisis perubahan berat badan sampel yang di uji dengan uji Kruskall wallis menunjukan bahwa terdapat perbedaan perubahan berat badan sebelum, setelah induksi STZ, dan setelah intervensi $(\mathrm{p}=0,000)$. Secara deskriptif perubahan berat badan sebelum dan setelah induksi STZ perubahan berat badan yang terendah yaitu pada kelompok perlakuan 1 sebesar 2,95\% dan perubahan berat badan yang tertinggi yaitu pada kelompok perlakuan 2 sebesar $5,67 \%$. Sedangkan perubahan berat badan setelah induksi STZ dan setelah intervensi, perubahan berat badan terendah yaitu pada kelompok kontrol positif sebesar $0,09 \%$ dan perubahan berat badan yang tertinggi yaitu pada kelompok kontrol negatif sebesar $18,6 \%$.

Penurunan berat badan sebelum dan setelah induksi STZ terjadi pada kelompok $\mathrm{K}(-)$, P1, dan P2. Sedangkan pada kelompok $K(+)$ berat badan sampel meningkat. Hal ini diakibatkan pada kelommpok $\mathrm{K}(+)$ tidak mendapat induksi STZ. Penurunan berat badan setelah induksi STZ dan setelah intervensi terjadi pada kelompok $\mathrm{K}(+)$ saja. Kelompok K (-), P1, dan P2 mengalami peningkatan berat badan. Kelompok K(-) tidak mengalami penurunan berat badan karena tidak tiberi induksi STZ. Penurunan berat badan umumnya terjadi pada tikus diabetes yang diinduksi STZ. Penurunan berat badan akibat induksi STZ \pm 2,9 g/hari. ${ }^{35}$ Penurunan berat badan pada tikus diabetes merupakan hasil dari penurunan protein karena ketidakmampuan karbohidrat untuk menjadi sumber energi. ${ }^{29}$ Berat badan tikus dapat meningkat kembali ketika diberikan perawatan hipoglikemik. ${ }^{35}$ Pemberian buah pisang kepok kuning di tujukan sebagai perawatan hipoglikemik yang diberikan pada kelompok P1 dan P2. Kelompok perlakuan mengalami perningkatan metabolisme glukosa sehingga berat badan meningkat. ${ }^{29}$

\section{Pengaruh Pisang Kepok Kuning terhadap Kadar Glukosa Darah}

Pisang kepok kuning diharapkan mampu menurunkan kadar glukosa darah. Pada penelitian ini menunjukan adanya perbedaan yang bermakna sebelum dan setelah intervensi pada kelompok kelompok perlakuan secara analisis. Secara deskriptif kadar glukosa darah setelah intervensi pada kelompok perlakuan 1 (pisang kepok kuning 4,5 g) dan perlakuan 2 (pisang kepok kuning $9 \mathrm{~g}$ ) 
mengalami penurunan masing-masing sebesar $47,05 \%$ dan $58,46 \%$.

Penurunan kadar glukosa darah disebabkan kandungan zat gizi berupa serat pangan yang terkandung di dalam pisang kepok kuning dan kandungan serat yang ada di pakan standart tikus. Pakan standart tikus menggandung serat sebanyak $6 \%$. Serat memiliki efek positif terhadap kadar glukosa darah serum. ${ }^{8}$ Serat pangan memiliki karakteristik dalam menurunkan waktu transit makanan dalam usus halus dan meningkatkan massa feses, dapat di fermentasi oleh mikroflora dalam usus besar, dan juga mampu menurunkan kadar glukosa darah dan kadar insulin. Serat pangan menghambat penyerapan glukosa di dalam pencernaan sehingga peningkatkan kadar glukosa darah dapat di tekan. Kadar glukosa darah sebanding dengan jumlah insulin yang dibutuhkan sehingga jika peningkatan kadar glukosa darah dapat di tekan maka produksi insulin akan menurun. Pisang kepok mengandung serat seperti pati resistan dan inulin. Pati resistan dapat menurunkan kadar glukosa darah postprandial dan kadar insulin. Pati resisten merupakan pati yang tidak dapat di cerna oleh enzim pencernaan usus halus dan ketika mencapai usus besar dimanfaatkan oleh bakteri dalam kolon sehingga dapat menjadi prebiotik.

Kandungan inulin di dalam pisang tidak sebanyak kandungan pati resisten di dalam pisang. Inulin juga memiliki peran terhadap kadar glukosa darah. Inulin adalah serat yang termasuk dalam golongan oligosakarida. Inulin merupakan serat larut air yang dapat terfermentasi di kolon sehingga inulin merupakan prebiotik. Inulin juga dikenal sebagai fruktan. Selain inulin pati resistan juga dapat terfermentasi di dalam kolon dan menjadi prebiotik. Inulin dan pati resisten difermentasi didalam jalur pencernaan (kolon) dan menghasilkan SCFA (Short Chain Fatty Acid) atau asam lemak rantai pendek. Asam lemak rantai pendek terdiri dari asetat, butirat dan propionat. Asam lemak rantai pendek dapat meningkatkan aktifitas dari bifidobakteria dan laktobacili di dalam usus yang dapat meningkatkan kesehatan tubuh dan berpengaruh pada metabolisme insulin di dalam tubuh sehingga efek hipoglikemik dapat terjadi. ${ }^{14}$

Asam asetat diserap ke dalam vena porta sehingga masuk ke hati dan pembuluh darah. Asam asetat digunakan sebagai sumber energi untuk jaringan besar non hepar. Asam propionat merupakan senyawa utama asam lemak rantai pendek yang dapat berperan dalam metabolisme glukosa. Asam propionat dimetabolisme di dalam hati dan memiliki kemampuan dalam menghambat glukoneogenesis dan meningkatkan glikolisis pada tikus. Sedangkan asam butirat digunakan sebagai sumber energi di sel epitel sepanjang kolon. Sehingga di antara jenis SCFA utama, asam propionat yang berperan terhadap kadar glukosa darah. Asam lemak rantai pendek yang diproduksi dalam kolon menyumbang 5-10\% energi yang dibutuhkan oleh tubuh. ${ }^{36}$

Selain serat, kandungan antioksidan di dalam pisang juga dapat menurunkan kadar glukosa darah puasa. Antioksidan yang terdapat pada pisang kepok kuning adalah $\beta$-karoten dan flavonoid. $\beta$ karoten merupakan antioksidan yang berperan sebagai hipoglikemik yang terjadi melalui mekanisme penghambatan radikal bebas dan dapat menekan lipid peroksida didalam jaringan sehingga dapat mengurangi komplikasi diabetes melitus. $\beta$ karoten mampu melindungi kerja pankreas dari radikal bebas dengan menginaktivasi radikal bebas sehingga pankreas dapat bekerja optimal dalam memproduksi insulin. Menurut penelitian Azza, pemberian $\beta$-karoten dapat menurunkan kadar glukosa darah dan dapat menjadi protektif pada kerusakan sel $\beta$ pankreas. $\beta$-karoten dapat memperbaiki kemampuan sel $\beta$ dalam sekresi insulin sehingga dapat menurunkan kadar glukosa darah. Insulin menurunkan glukosa darah dengan meningkatkan transfer glukosa, ikatan insulin dan reseptornya membutuhkan GLUT 4 untuk dapat masuk ke dalam sel otot dan jaringan lemak serta ambilan glukosa dengan efisien sehingga dapat menurunkan kadar glukosa darah. ${ }^{20}$ Flavonoid pada pisang dapat meningkatkan sensitifitas insulin dengan membersihkan jalur sinyal insulin. Flavonoid dalam pisang berpotensi untuk mengaktivasi insulin reseptor tiroksin kinase pada proses insulin signaling. Pada pasien diabetes melitus aktifitas tyroksine kinase terhambat. ${ }^{37}$

\section{SIMPULAN}

Kesimpulan yang di dapat dari penelitian ini adalah pemberian pisang kepok kuning selama 21 hari pada dosis 4,5 g/200 g BB/hari dan $9 \mathrm{~g} / 200$ g BB/hari dapat menurunkan kadar glukosa darah masing-masing sebesar $47,05 \%$ dan $58,46 \%$ pada tikus sprague dawley pra sindrom metabolik.

\section{DAFTAR PUSTAKA}

1. Grundy SM. Metabolic Syndrome Pandemic. Arter. Thromb Vasc Biol. 2008;28:629-636.

2. Beltrán-sánchez H, Harhay MO, Harhay MM, Mcelligott S. Prevalence and Trends of Metabolic Syndrome in the Adult U . S . Population, 1999 2010. Am. Coll. Cardiol. 2013;62(8):697-704.

3. Dwipayana M, Suastika K, Saraswati I. Prevalensi Sindroma Metabolik pada populasi Penduduk Bali, Indonesia. J Peny Dalam. 2011;12(1):1-5. 
4. National Cholesterol Education Program criteria modified for Asians (NCEP ATP III) Expert Panel on Detection, Evaluation, and Treatment of High Blood Cholesterol in Adults. JAMA 2001;285:2486-97.

5. Rodriques RA, Sulchan M. Kadar pro-inflamator sitokin interleukin (il) - 18 pada remaja obesitas dengan sindrom metabolik. 2014;(Il):1-24.

6. Eckel R, Grundy S, Zimmet P. The metabolic syndrome. 2005;365:1415-1428.

7. Rolfes SR, Pinna K, Ellie W. The Carbohydrates: Sugars, starches, fibers. In: Understanding normal and clinical nutrition. Eighth. Canada; 2009:100 125.

8. Nelms M, Sucher K, Lacey K, Roth S. Nutrition Therapy and Phatophysiology. In: Cosio Y, ed. Cengage Learning. Inc. Second. California; 2010:669-671.

Available www.cengange.com/Wadswoeth.

9. Rolfes SR, Pinna K, Ellie W. Diabetes melitus. In: Understanding normal and clinical nutrition. Eighth. Canada; 2009:811-833.

10. Bintari S, Nugraheni K. Penurunan kadar gula darah akibat pemberian extra virgin olive oil. J. MIPA. 2012;35(0215):116-121.

11. Rianti C, Syauqy A. Pengaruh Pemberian Pisang (Musa paradisiaca) terhadap Kelelahan Otot Aerob pada Atlet Sepak Takraw. 2014:1-25.

12. Kumairoh S, Syauqy A. Pengaruh Pemberian Pisang (Musa paradisiaca) terhadap Kelelahan Otot Anaerob Pada Atlet Sepak Takraw. 2014:1-17.

13. Cressey R, Kumsaiyai W, Mangklabruks A. Daily consumption of banana marginally improves blood glucose and lipid profile in hypercholesterolemic subjects and increases serum adiponectin in type 2 diabetic patients. Indian J. Exp. Biol. 2014;52(December):1173-1181.

14. Slavin J. Fiber and Prebiotics: Mechanisms and Health Benefits. Nutrients. 2013;5:1417-1435.

15. Desnilasari D, Lestari N. Formulasi minuman sinbiotik dengan penambahan puree pisang ambon( Musa paradisiaca var sapientum ) dan inulin menggunakan inokulum Lactobacillus casei. Agritech. 2014;34(3):257-265.

16. Musita N. Kajian kandungan dan karakteristik ati resisten dari berbagai varietas pisang. J. Teknol. Ind. dan Has. Pertan. 2009;14(1):68-79.

17. Lattimer JM, Haub MD. Effects of Dietary Fiber and Its Components on Metabolic Health. Nutrients. 2010;2:1266-1289.

18. Roberfroid M. Inulin-Type Fructans: Fungsional Food Ingredients. CRC Press. 2005.

19. Wahyuningtyas N. Laporan Praktek Produksi Pembuatan Kerupuk dengan Substitusi Pisang Kepok Kuning (Musa Balbisiana). Surakarta; 2011:6-7.

20. Soviana E, Rachmawati B, W NS. Pengaruh suplementasi $\beta$-carotene terhadap kadar glukosa darah dan kadar malondialdehida pada tikus sprague dawley yang diinduksi Streptozotocin. Jural Gizi Indones. 2014;2(2):41-46.

21. Musfiroh I, Indriyati W, Muchtaridi. Analisis Proksimat dan Penetapan Kadar $\beta$ - Karoten dalam Selai Lembaran Terung Belanda (Cyphomadra betacea Sendtn.) dengan Metode Spektrofotometri Sinar Tampak. 2007:1-8.

22. Musa K, Abdullah A, Jusoh K, Subramaniam V. Antioxidant Activity of Pink-Flesh Guava ( Psidium guajava L .): Effect of Extraction Techniques and Solvents Antioxidant Activity of Pink-Flesh Guava ( Psidium guajava L .): Effect of Extraction Techniques and Solvents. Food Anal. Methods. 2011;4(August):100-107.

23. Retnaningtyas Y. Determination of Inulin From Multivitamin Syrup Product By High Performance Liquid Chromatography With RI Detector. Indo. J. Chem. 2012;12(2):201-205.

24. Szkudelski T. Steptozotocin-nicotinamide-induced diabetes in rat characteristics of the experimental model. Exp. Biol. Med. 2012;5(237):481-490.

25. Dahlan M. Statistik Untuk Kedokteran dan Kesehatan. edisi 5. (Suslia A, ed.). Jakarta: Salemba Medika; 2011.

26. Koswara S. Teknologi Tepat Guna Pengelolahan Singkong, Pisang, dan Talas.; 2009. Available at: Ebookpangan.com.

27. Retnaningtyas Y, Wulandari L, Sari RM. Penentuan kadar inulin dalam ekstrak buah pisang ( Musa paradisiaca , Linn .) sebagai prebiotik dengan metode KLT-Densitometri. Fak. Farm. Univ. Jember.

28. Damasceno DC, Netto AO, Iessi IL, et al. Streptozotocin-Induced Diabetes Models : Pathophysiological Mechanisms and Fetal Outcomes. Biomed Res. Int. 2014.

29. Sathishsekar D, Subramanian S. Antioxidant properties of Momordica Charantia ( bitter gourd ) seeds on Streptozotocin induced diabetic rats. Asia Pac J Clin Nutr. 2005;14(February):153-158.

30. Mythilli M, Vyas R, Akila G, Gunaserkaran S. Effect of Streptozotocin on the Ultrastucture of Rat Pancreatic Islet. Microsc. Res. Tech. 2004;(63):274-281.

31. Lenzen S. The mechanisms of alloxan- and streptozotocin-induced diabetes. Diabetologia. 2008;51:216-226.

32. Srinivasan K, Ramarao P. Animal models in type 2 diabetes research : An overview. Indian J Med Res. 2007;125(March):451-472.

33. Mitruka B, Rawnsley H. Clinical Biochemical and Hematological Reference Values in Normal Experimental Animals and Normal Humans. 2 edition. (Masson, ed.). USA Inc; 1981.

34. Koolman J, Roehm KH. Color Atlas of Biochemistry Second edition, revised and enlarged. New York; 2005:160-162.

35. Hwang H, Kim S, Lim J, et al. Hypoglycemic effect of crude exopolysaccharides produced by a medicinal mushroom Phellinus baumii in 
streptozotocin-induced diabetic rats. Life Sci. 2005;76:3069-3080. Available at: www.sciencedirect.com.

36. Yofananda O, Estiasih T. Potensi Senyawa Bioaktif Umbi-umbian Lokal Sebagai Penurun Kadar Glukosa Darah: Kajian Puataka. J. Pangan dan Agroindustri. 2016;4(1):410-416.

37. Ganugapati J, Baldwa A, Lalani S. Molecular docking studies of banana flower flavonoids as insulin receptor tyrosine kinase activators as a cure for diabetes mellitus. 2012;8(5). 